\title{
On a new species of the genus Moenkhausia Eigenmann (Ostariophysi: Characidae)
}

\author{
PAULO H. F. LUCINDA ${ }^{1}$, LUIZ R. MALABARBA ${ }^{2} \&$ RICARDO C. BENINE ${ }^{3}$ \\ ${ }^{1}$ Laboratório de Ictiologia Sistemática, Universidade Federal do Tocantins, Campus de Porto Nacional, Rua 3, Quadra 17, s/n, \\ Jardim dos Ipês, 77.500-000, Porto Nacional, TO, Brazil.E-mail: PHFL.E-mail: lucinda@pesquisador.cnpq.br, lucinda@uft.edu.br \\ ${ }^{2}$ Laboratório de Ictiologia, Museu de Ciências e Tecnologia, PUCRS, Av. Ipiranga 6681, 90.619-900, Porto Alegre, RS, Brazil, and \\ Departamento de Zoologia, IB, Universidade Federal do Rio Grande do Sul, Av. Bento Gonçalves, 9500, bloco IV, Prédio 43435, \\ 91501-970, Porto Alegre, RS, Brazil.E-mail: malabarb@ufrgs.br \\ ${ }^{3}$ Laboratório de Biologia e Genética de Peixes, Departamento de Morfologia, Instituto de Biociências,Universidade Estadual \\ Paulista, Campus de Botucatu. Distrito de Rubião Júnior, S/N, 18618-000, Botucatu, SP, Brazil. E-mail: rbenine@hotmail.com
}

\begin{abstract}
A new species of the genus Moenkhausia is described from the middle portions of the Rio Tocantins and tentatively from the Río Apure in Venezuela, Río Orinoco drainage. It is diagnosed by the presence of a dark spot in the half proximal length of the upper caudal-fin lobe, and by the presence of a large, irregularly shaped humeral spot located above the sixth to ninth perforated lateral line scale which is more posteriorly positioned along the body side in relation to other members of the genus. The distribution pattern of the new species is discussed.
\end{abstract}

Key words: Neotropical tetras, Biogeography, Systematics

\section{Resumo}

Uma nova espécie do gênero Moenkhausia é descrita da porção média das drenagens do Rio Tocantins e tentativamente do Rio Apure na Venezuela, Sistema do Rio Orinoco. Ela é diagnosticável pela presença de uma mácula escura na porção média do lobo superior da nadadeira caudal associada a presença de uma grande mancha umeral de formato irregular localizada acima da sexta a nona escamas perfuradas da linha lateral e mais posteriormente no corpo em relação a outras espécies do gênero. Discute-se o seu padrão de distribuição.

\section{Introduction}

The genus Moenkhausia was erected by Eigenmann (1903) and is currently defined by the presence of premaxillary teeth in two parallel rows, five or more teeth in the inner premaxillary tooth row, a completely pored lateral line, and scaled caudal-fin lobes (see Eigenmann, 1917). Presently, the genus comprises 63 valid species of small characids largely distributed in South America drainages of the Río Orinoco, Rio Amazonas, Rio Tocantins-Araguaia, Rio Paraguay, Rio Uruguay and Rio Doce. (Lima et al., 2003; Eschmeyer's Online Cata$\log$ of Fishes, 2006).

Examination of collections of characid fishes deposited in the Laboratório de Ictiologia Sistemática da Universidade Federal do Tocantins (UNT) has revealed the presence of an undescribed species of Moenkhausia from the middle portion of the Rio Tocantins. Further examination of material from the Museo de Ciencias 